\title{
Evaluation of Plant Diversity in the Steppes of White Wormwood of the Region of Saida (Western Algeria)
}

\author{
Saidi Abdelmoumen*, Mehdadi Zoheir \\ Laboratory of Plant Biodiversity: Conservation and Valorization, University of Djillali Liabes, Sidi Bel Abbes, \\ Algeria \\ Email: ${ }^{*}$ saidimoumen@yahoo.fr
}

Received 9 August 2015; accepted 9 October 2015; published 12 October 2015

Copyright (C) 2015 by authors and Scientific Research Publishing Inc.

This work is licensed under the Creative Commons Attribution International License (CC BY). http://creativecommons.org/licenses/by/4.0/

c) (7) Open Access

\begin{abstract}
This work is an evaluation of the plant diversity of the white Wormwood formations (Artemisia herba-alba Asso.) in the steppes rangelands of the south-eastern zone of Saïda (municipality of Mâamora, Western Algeria). For this purpose, twenty-one phytoecological statements are carried out on three sample stations: an exclosure station where the white Wormwood is well developed and two other stations not protected where in one, the white Wormwood is moderately degraded and in the other one, it is strongly degraded. The factorial correspondences analysis (FCA) and the ascending hierarchical clustering (AHC) carried out on the floristic and edaphic parameters measured on these stations led to a hierarchy of the ecological factors determining the diversity of the studied plant formations with white Wormwood. The vegetation studied is marked by the dominance of the therophytes, particularly in the third station (very degraded station), while the exclosure station is essentially characterized by a high recovery rate and an important phytomass.
\end{abstract}

\section{Keywords}

Plant Diversity, Steppe, Artemisia herba-alba Asso., FAC, AHC

\section{Introduction}

The natural and ecological resources constitute a richness whose degradation represents a constraint to the human development, economics and a threat for social balance. The steppe vegetation plays a fundamental role in the structure and the running of the steppe ecosystem where it constitutes an expression of the biological poten-

*Corresponding author.

How to cite this paper: Abdelmoumen, S. and Zoheir, M. (2015) Evaluation of Plant Diversity in the Steppes of White Wormwood of the Region of Saida (Western Algeria). Open Journal of Ecology, 5, 491-500.

http://dx.doi.org/10.4236/oje.2015.510040 
tial. However, natural vegetable cover is subjected to a double stress edaphic and climatic, on the one hand and anthropic, on the other hand [1]-[3].

Among the characteristic plants of the steppe landscape, the white wormwood (Artemisia herba-alba Asso.) by morphological and physiological characteristics represents a species well adapted to the arid climatic conditions. The white wormwood steppes by their extent, their homogeneity and their pastoral interest, constitute the current facies of the steppe area in south of Oran (Western Algeria). The vast areas are covered by these facies north of chotts Ech-chergui and gharbi along a band of $250 \mathrm{~km}$ [4]. Such as other steppe formations, the formations of white wormwood are in continuous degradation, under the pressure of the anthropic and climatic effects, which worsens the process of the desertification [5]. This results in a gradual reduction of the biological potential and reduces quantitatively and qualitatively the productive capacity of the natural environment. This decline is accompanied in some cases by a decrease in species richness and installation of a "banal flora" without interest to humans and animals [6].

The knowledge of the natural vegetation as a reflection of ecological conditions must allow a preliminary diagnosis, which can direct improvement actions and development of the steppe region [7] [8]. From this point of view, this work is registered whose objective is to highlight, by a phytoecological approach, the state of the phytodiversity in the steppe zone of Saïda (western of Algeria), particularly in the steppe of white wormwood in the municipality of Mâamora that unfortunately as other steppiques zones, remains subjected to a strong degradation. Let us note that no work of this kind has been carried out in the zone of study.

\section{Materials \& Methods}

The study area is part of the high steppe plains of south oranians (municipality of Maâmora, Wilaya of Saida, west of Algeria). It is located between $0^{\circ}$ and $1^{\circ}$ longitude and $34^{\circ}$ and $35^{\circ}$ of northern latitude.

In accordance with the climatic data of the period 1978-2010 [9], the study area is characterized by a semiarid climate with a fresh winter. Annual rainfall averages oscillate around $345 \mathrm{~mm}$ with a regime of type WSAS (winter-spring-autumn-summer) and the monthly average temperatures are between $8.3^{\circ} \mathrm{C}$ and $27.1^{\circ} \mathrm{C}$. The dry period extends over a period of six months (from May to October).

In this study area, three stations are selected for our investigations:

- station 1: rangeland exclosure by the High Commission at the Development of Steppe (HCDS) since 2008, with a surface of 7000 ha, where the white wormwood is well developed (rate of total recovery $=59 \%$, including 32\% for the white wormwood);

- station 2: rangeland of white wormwood fairly degraded (rate of total recovery $=26 \%$, including $12 \%$ for the white wormwood), with a surface of 2700 ha;

- station 3: rangeland of white wormwood strongly degraded, subjected to a strong anthropic pressure with a surface of 1600 ha (rate of total recovery $=14 \%$ including $8 \%$ for the white wormwood).

For the study of the vegetation, we adopted the method stigmatist of Braun Blanquet [10] which consists in taking floristic statements in period of optimal development of the vegetation, from April to May 2013. Twenty-one floristic statements are carried out with a rate of seven statements chosen randomly in each of the three stations. For every statement, we adopted a minimal area of $100 \mathrm{~m}^{2}$ [11]. The selection of the sites of the statements is made by software MAP information for the choice of the points on the map and a GPS (GARMIN12 channels) for the materialization of these points on the field.

For each statement are noted the altitude, the rate of recovery and phytomass of the vegetation. The inventoried species are determined by using the flora of Algeria of Quézel and Santa [12], then divided in families, biological and biogeographic types corresponding. The determination of the total recovery is performed by the calculation of the projection surface of the air device of the vegetation studied compared to the total surface of the statement.

The estimate of aerial phytomass is made, in each statement, by whole mowing of the aerial part of the vegetation on a surface of $1 \mathrm{~m}^{2}$, then brought back in paper bags to the laboratory for drying and weighing [13].

Three pedological statements were carried out in each station, on the level of each statement, the physicochemical analyses are carried out on taken samples of soil of the surface horizon, whose properties are often related to the human, agricultural or pastoral disturbances [14]. These analyses consist to evaluate texture, moisture, electric conductivity, $\mathrm{pH}$, rate of total limestone and rate of organic matter [15].

The indices of similarity of Sorensen and Jaccard are used to compare the similarity of the floristic composi- 
tion of the three stations; the indices of diversity of Shannon and equitability are used to evaluate their specific diversity [16] [17]. For the statistical processing of the results of the floristic and pedological analyses, we used the factorial correspondences analysis (FCA) and the ascending hierarchical classification (AHC). The FCA informs on the affinities between the analyzed elements. In our case, this analysis provides information about ecological affinities of the stations explored and the plant species which there are submit [18] [19]. The AHC allows to individualize the limits between the various variables [20].

\section{Results \& Discussion}

On Table 1 is represented the floristic list of the species inventoried in the three stations studied with their coefficients of abundance-dominance and sociability. 53 different species are listed in the three stations: 43 in the station 1 , 39 in the station 2 and 31 in the station 3 . On the 53 listed species, $43 \%$ are common to the three stations, $13 \%$ are exclusive for the station $1,9 \%$ of the station 2 and $7 \%$ for the station 3 .

The floristic richness of arid region depends primarily on the annual species, environmental conditions and the correlation of the whole of the characters (climate, edaphic conditions and exploitation) [21]. In accordance with the classification of Daget and Poissonet [22], the floristic census carried out indicates a rather important floristic richness in the stations 2 (39 species) and 3 (31 species) and important in the station 1 (43 species) (Table 1). This richness Compared to some past years [9] is explained by the remarkable rainfall $(517 \mathrm{~mm})$ recorded in the area of study during the year of execution of the statements (2013), which has favored the development of the therophytes whose contribution in the floristic composition exceeds 60\%, according Daget [23], the appearance of the therophtes is strictly linked to seasonal rains.

From a point of view taxonomic, the inventoried species belong to 21 families (Figure 1). The most represented family is that of the Asteraceae with a rate of $19 \%$ for the station 1, 15\% for the station 2 and $29 \%$ for the station 3. Then are placed in decreasing order the Poaceae (station 1: 12\%, station 2: $18 \%$ and station 3: $16 \%$ ). These

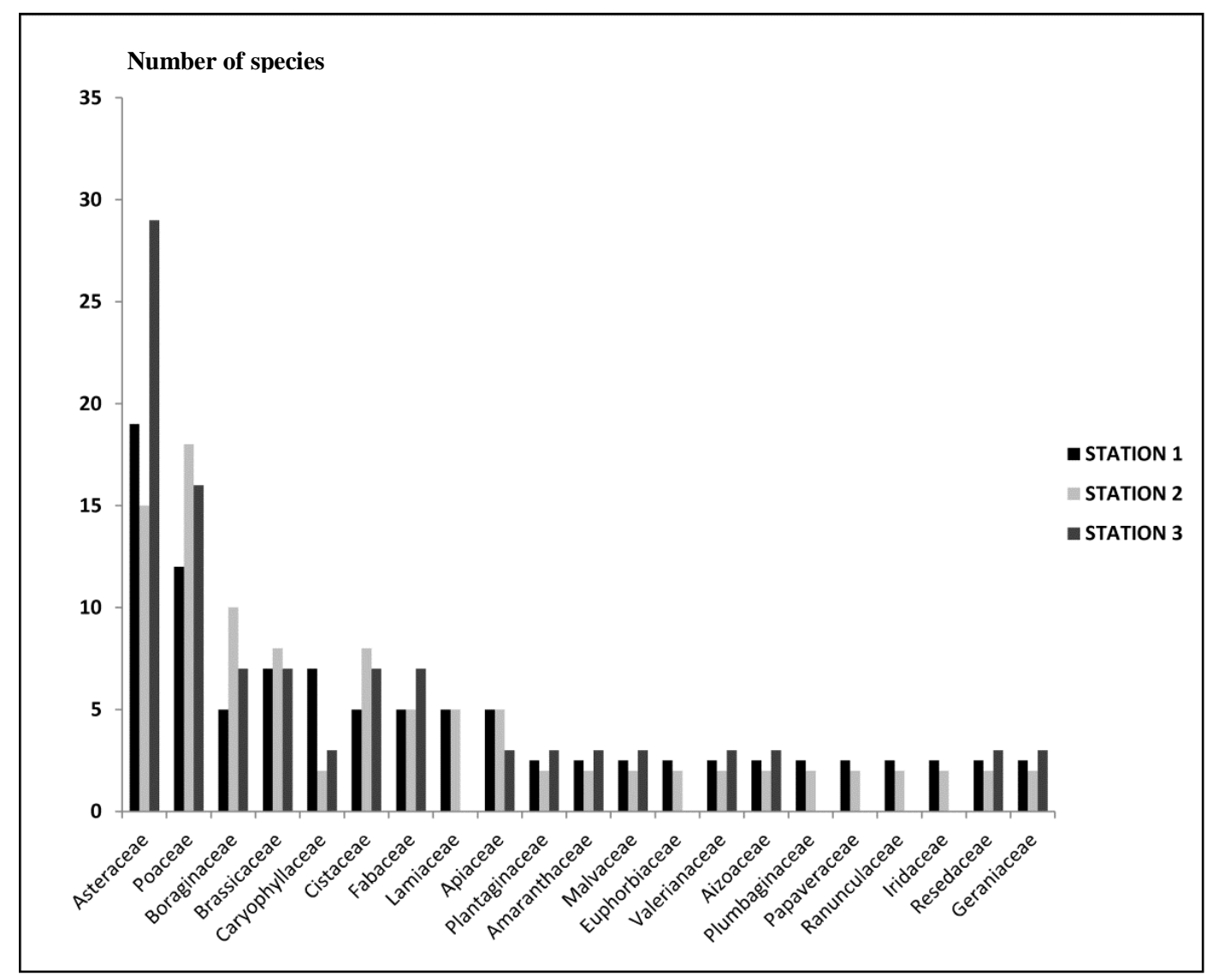

Figure 1. Biological specter of the vegetation in the three stations. 


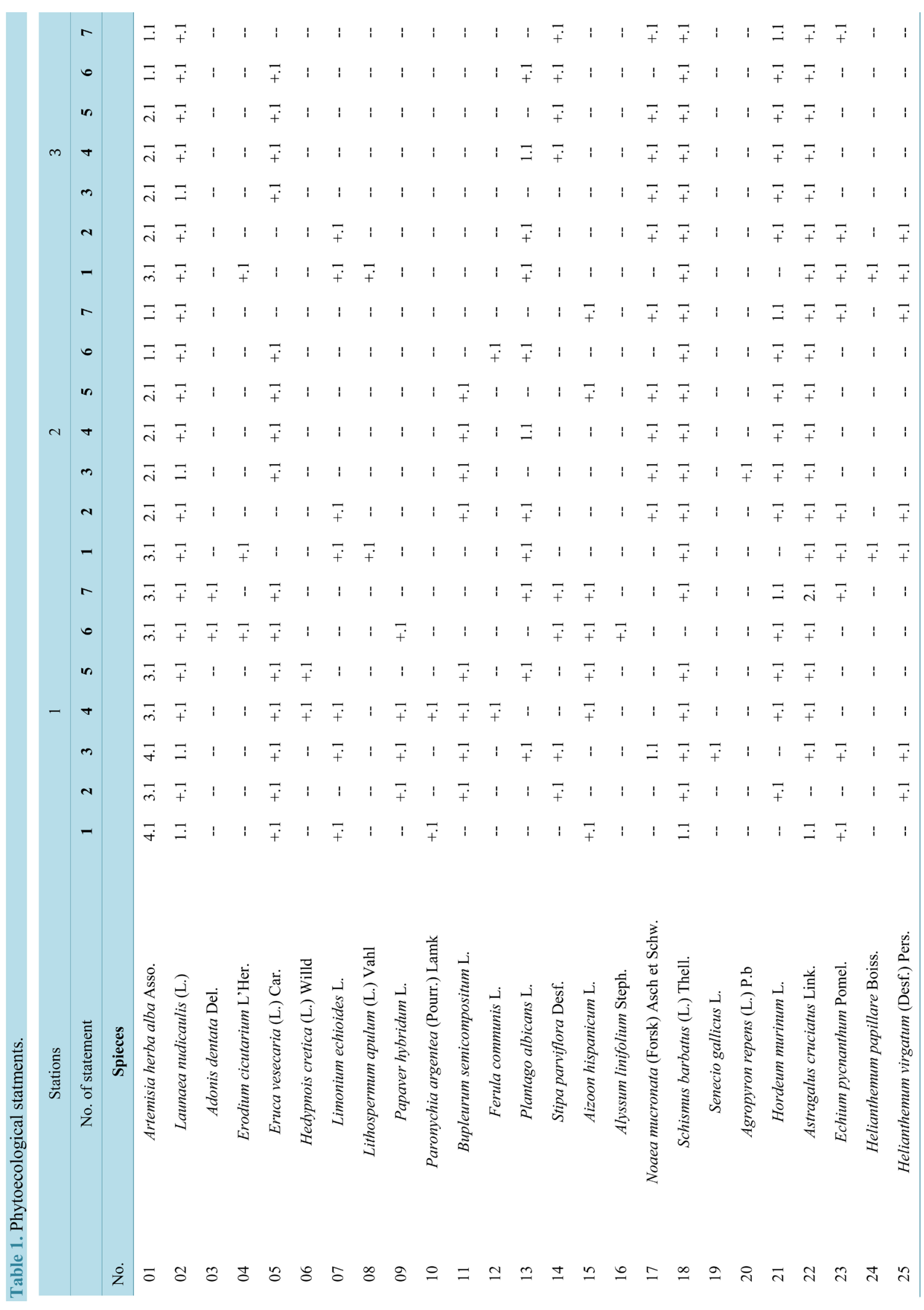




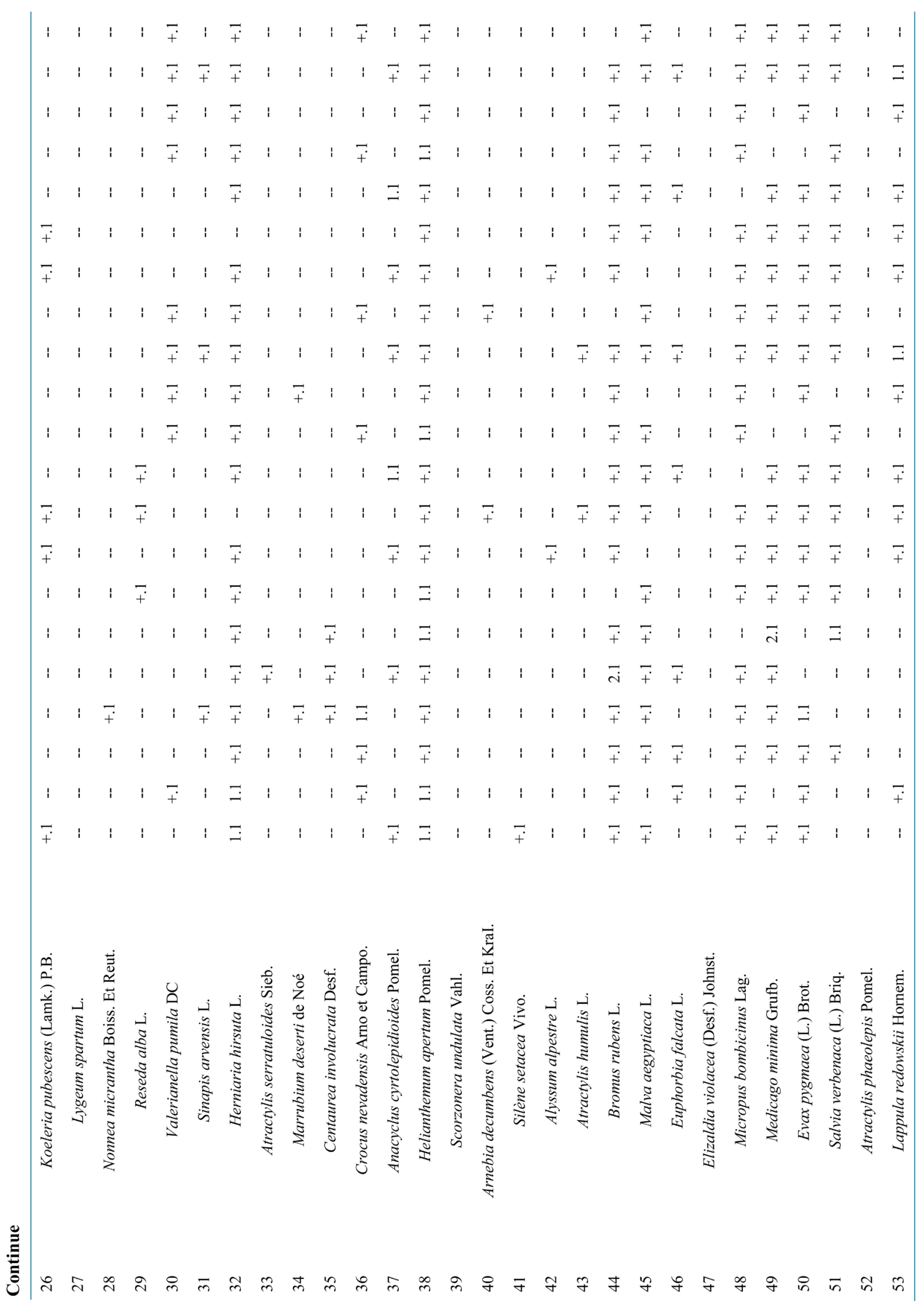


two families adapt well in the arid and semi-arid areas, they are very widespread in the entire steppe and the Saharian Atlas [24]. According to the same author, they represent with Fabaceae 35\% to 40\% of the flora of the Saharean sector. Then come the Boraginaceae (station 1: 5\%; station 2: 10\% and station 3: 7\%); the Brassicaceae (stations 1 and 3: 7\%, station 2: 8\%); the Cistaceae, the Fabaceae and the Lamiaceae are distributed in the three stations with rates ranging between $5 \%$ and $8 \%$; the remaining families are poorly represented (2\% to $3 \%$ ).

The analysis of the biological spectrum of the vegetation shows the prevalence of the therophytes with a rate of $62 \%$ in the station 1, 64\% in the station 2 and $67 \%$ in the station 3 (Figure 2). This therophytisation is a characteristic of the arid zones and expresses the strategy of adaptation towards the unfavorable conditions and a shape of resistance to the rigors climatic [23] [25] [26]. The contribution of the hemicryptophytes in the whole of the flora of the study area is with $21 \%$, including $24 \%$ in the station $1,23 \%$ in the station 2 and $19 \%$ in the station 3 . The chamaephytes are presented with a rate between $10 \%$ and $12 \%$ for the three stations, they adapt better to the summer drought and the strong illuminations [27] [28]. The geophytes are slightly represented in the three stations (station 1: 2\%; station 2: 3\%; station 3: 4\%); this joined the remarks of Barbero et al. [29] according to which the geophytes regress and disappear in the lawns and steppe zones. However, the phanerophytes are absent, thus confirming the works of Kadi-Hanifi [30] [31] who underline that the phanerophytes occupied the last position of the biological types in the steppe formations of Algeria.

The analysis of the phytogeographical spectrum shows the dominance of the species of Mediterranean affinity, they account $27 \%$ for the station $1,23 \%$ for the station 2 and $19 \%$ for the station 3 , reflecting the affiliation of the steppes studied to the Mediterranean region. This confirmation is consensual between the whole of the works on the North African steppes [32] [33]. The endemic species represent approximately 10\% of the flora of the area (station 1: $9 \%$, station 2: $8 \%$ and station 3: 10\%). This order of magnitude of this type is confirmed in the arid steppes of North Africa by several authors [33] [30] [34]. The types Mediterra-Irano-Turanian and WestMediterranean account 6\% of the territory explored. The biogeographical origins Macaro-Mediterranean, MedSaharo-Arabic, Med-Saharan, Circumboreal, Ibero-Mauretanean, Eurasean, Saharo-Arabic, Paleo-moderate, Saharan and endemic Algero-Morrocan are represented each one with a rate of $4 \%$ in the three stations.

The global recovery is an important parameter state indicator of the vegetation and biodiversity [11]. It varies from one station to another (Table 1): weak (14\%) for the station 3 where the anthropic action is the main cause of this weakness, medium for the station 2 (26\%), on the other hand, in the station 1 (59\%) the recovery is better, thus putting the favorable effect of the exclosure in the biological increase reflected the good development of the perennial and annual vegetation and consequently the improvement of the edaphic conditions. These observations are similar to those of Henni and Mehdadi [26] on the steppes of white wormwood degraded and rehabilitated by the plantation of Atriplex in the area of Saïda (Western Algeria). In addition, according to Le Houerou [33], the biologic ascent is all the inverse processes of those of the steppisation and the desertisation. It is characterized by the increase of the rate of permanent recovery of the long-lasting biomass, the rate of organic matter in the soil, the structural stability, the permeability and the water balance, the biologic activity and the primary productivity. The basal recovery of the white wormwood, dominant species, is about $32 \%$ for the station $1,12 \%$ and $8 \%$

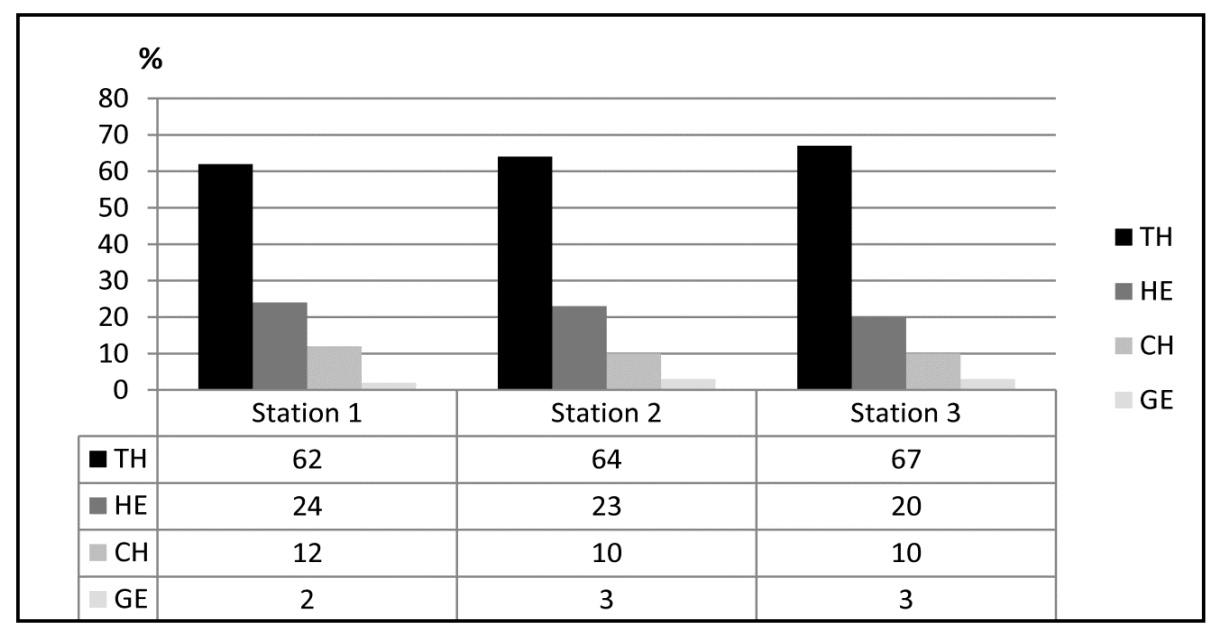

Figure 2. Biological specter of the three stations. 
respectively for the stations 2 and 3, of the Table 1, it emerges that the basal recovery is correlated with the global recovery; the contribution of the white wormwood in the global recovery is about $54 \%$ for the first station, $46 \%$ and $47 \%$ respectively for the second and the third station.

The phytomass varies also from a station to another (Table 1): it is important in the station 1 (1650 kg MS/ha), reflecting yet the positive effect of the exclosure on the production of the biomass. The deletion of the grazing has allowed the reconstruction and the remarkable regeneration of the vegetation. This is not the case for the station 3 (330 kg MS/ha) subjected to a permanent grazing where his biomass is low. While that we recorded a medium phytomass in the station 2 (860 kg MS/ha).

The pedological analyses made on the soils of the study area show that the soil texture of the three stations is silt-sandy, these results are also obtained by Benabadji et al. [35] in the region of Sebdou (wilaya of Tlemcen, West of Algeria). We note a slight improvement of the rate of moisture of the soil in the station 1 compared to the stations 2 and 3 (5.2\% station 1; 4.1\% station $2 ; 2.9 \%$ station 3 ), resulting mainly of the good protection of this latter against the wind erosion and the drying due essentially to the better rate of recovery of the vegetation. The rate of total limestone is considerable in three stations (Table 2); this is justified by the presence of a limestone slab near the surface, typical of steppe soils [19]. The depth is significant for the first station compared to other stations (Table 2); this is due to the better rate of recovery and the protection of this station against the wind and hydric erosion. The soil in the three stations is not very saline with an electric conductivity ranging between 0.03 and $0.47 \mathrm{~ms} / \mathrm{cm}$ and with alkaline $\mathrm{pH}$ (8.70 to 8.90$)$. The rate of moisture is between $2 \%$ and $5 \%$ and for the organic matter is low (1.78\% to $2.45 \%)$.

The indices of floristic similarity of Sorensen and Jaccard are higher than 60\% (Table 3), which means that more than a half of the floristic procession is common for the all of the stations. The values of the Shannon indice present slight variation between the three stations: 3.66 bits/individual for the third station, 4.01 bits/individual for

Table 2. Physico-chemical analysis of the soil of the three stations.

\begin{tabular}{|c|c|c|c|c|c|c|c|c|c|c|c|}
\hline & Profiles & $\begin{array}{c}\text { Depth } \\
\text { (cm) }\end{array}$ & $\begin{array}{l}\text { Sand } \\
(\%)\end{array}$ & $\begin{array}{l}\text { Slay } \\
(\%)\end{array}$ & $\begin{array}{l}\text { Silt } \\
\text { (\%) }\end{array}$ & Texture & $\begin{array}{l}\text { Moisture } \\
(\%)\end{array}$ & $\begin{array}{c}\text { Salinity } \\
\text { (mmhos/ } \\
\text { cm) }\end{array}$ & $\begin{array}{c}\text { Organic matter } \\
(\%)\end{array}$ & $\mathbf{p H}$ & $\begin{array}{c}\text { Total } \\
\text { limestone } \\
(\%)\end{array}$ \\
\hline \multirow{3}{*}{ Station 1} & $\mathrm{R} 1$ & 8 & 57 & 13 & 30 & & 5.8 & 0.03 & 1.84 & 8.9 & 14.7 \\
\hline & $\mathrm{R} 2$ & 15 & 63 & 9 & 28 & Silty-sand & 4.7 & 0.02 & 2.9 & 8.75 & 17.32 \\
\hline & R3 & 10 & 54 & 9 & 37 & & 5.1 & 0.07 & 2.6 & 8.85 & 17.32 \\
\hline \multirow[t]{2}{*}{ Average } & & 11 & 58 & 10 & 32 & -- & 5.2 & 0.04 & 2.45 & 8.83 & 15.97 \\
\hline & $\mathrm{R} 1$ & 9 & 67 & 3 & 30 & & 3.8 & 0.04 & 2 & 8.88 & 14.53 \\
\hline \multirow[t]{2}{*}{ Station 2} & $\mathrm{R} 2$ & 8 & 62 & 8 & 30 & Silty-sand & 5.2 & 0.18 & 0.46 & 8.87 & 18.45 \\
\hline & $\mathrm{R} 3$ & 7 & 62 & 10 & 28 & & 3.5 & 0.04 & 1.7 & 8.7 & 16.81 \\
\hline \multirow[t]{2}{*}{ Average } & & 8 & 64 & 7 & 29 & -- & 4.17 & 0.09 & 1.39 & 8.82 & 16.59 \\
\hline & $\mathrm{R} 1$ & 6 & 58 & 13 & 27 & & 3.1 & 0.47 & 1.78 & 8.88 & 19.27 \\
\hline \multirow[t]{2}{*}{ Station 3} & R2 & 5 & 61 & 10 & 32 & Silty-sand & 2.5 & 0.14 & 2.23 & 8.69 & 22.47 \\
\hline & R3 & 7 & 62.5 & 11.5 & 25 & & 3.2 & 0.22 & 1.9 & 8.74 & 25.43 \\
\hline Average & & 6 & 60.5 & 11.5 & 28 & -- & 2.93 & 0.28 & 1.97 & 8.77 & 22.39 \\
\hline
\end{tabular}

Table 3. Floristic similarity and species diversity of the three stations.

\begin{tabular}{|c|c|c|c|}
\hline & \multicolumn{3}{c}{ Species diversity and evenness of the three stations } \\
\hline & Station $\mathbf{1}$ & Station $\mathbf{2}$ & \multicolumn{1}{c|}{ Station $\mathbf{3}$} \\
\hline Shannon diversity index (bits/individual) & 3.90 & 4.01 & 3.66 \\
Equitability [E] & 0.86 & 0.88 & 0.81 \\
\hline & \multicolumn{2}{c}{ Floristic similarity between the three stations } \\
\hline Sorensen index & Station 1 - Station 2 & Station 1 - Station 3 & Station 1 - Station 3 \\
\hline Jaccard index & 0.80 & 0.70 & 0.69 \\
\hline
\end{tabular}


the second station and 3.90 bits/individual for the first station. These values translate, in the three stations, a specific richeness stable of quantitative and qualitative a point of view. The values of the indice of equitability are comparable for the three stations (station 1: 0.86 ; station 2: 0.88 ; station 3: 0.81 ), thus representing an equal distribution of the species.

In the FCA carried out on the edaphic and floristic parameters of the three stations (Figure 3), the plan F1-F2 is retained because it gives an account of a maximum of information (Fact. 1: 99.38\% and Fact. 2: $0.61 \%$ ) on the existing correlations between the three stations and their floristic and edaphic characteristics.

On the axis F1, two distinct groups separate. The formation of these two groups is supported by the ascending hierarchical clustering (AHC) carried out in parallel. The group 1 is represented by the stations 1 (st 1 ) which is an exclosure station where the wormwood is well developed and the station 2 (st 2) which is moderately degraded. These two stations are correlated with chamaephytes (Ch), hemicryptophytes (He), organic matter (OM), rate of recovery (Gc), phytomass (phyto), $\mathrm{pH}$, soil depth (SDe) and moisture (Hu). We note that on this group emerged, the state of the plant cover in particular the global recovery and the phytomass reflect the slight improvement of the edaphic characteristics in both stations 1 (st 1) and the station 2 (st 2), which confirms that these two stations are more rich at least in floral point of view and have some edaphic characteristics better than those of the station 3 (very degraded station). This is in particular case about some parameters, namely the organic matter, the depth of the soil and the humidity.

The group 2, represented by the station 3, is correlated to therophytes (Th), clays (A), total limestone (CT), geophytes (Ge) and sands (Sa). All these variables represent indicators of degradation, as a result, consequence of the anthropic impact.

Besides, the axis F1 of the FAC indicates a regressive evolution of the environment, related to a gradient anthropic, expressed in positive side towards the negative side and inversely for the recovery and phytomass that translate a progressive evolution of the environment, in negative side towards the positive side of this axis.

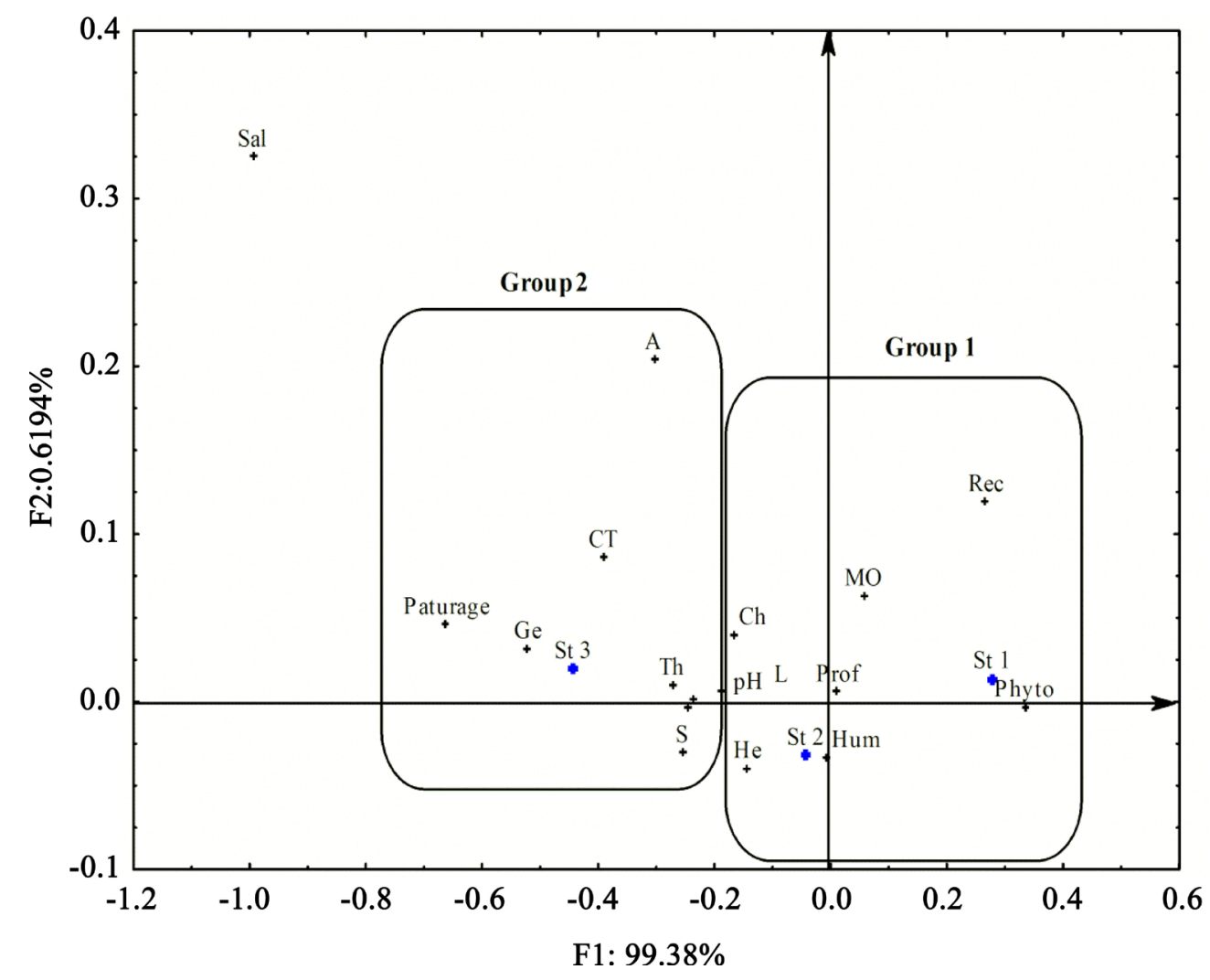

Figure 3. Factorial analysis of the correspondences. Gc: global covering of the vegetation; He: hemicryptophytes; Ch: chamaephytes; Th: therophytes; Ge: geophytes; Phyto: phytomass; SDe: soil depth; Hu: soil moisture; OM: organic matter; L: Silt; Sa: sand; Cl: clay; Tl: total limestone; Sal: soil salinity; St 1: station 1; St 2: station 2; St 3: station 3. 


\section{Conclusions}

The results obtained have allowed us to establish a preliminary assessment of the plant diversity of the steppe with the white wormwood of the municipality of Maâmora in the wilaya of Saida (west of Algeria). In fact, if we refer to the classification of Daget and Poissonet [22], a floristic richness between enough important and important, characterized the three stations sampled. This is not the case for the recovery of the vegetation and the phytomass which are best in the exclosure station, compared to the other two stations subject to the anthropic pressure. The three stations also have a similar floristic composition confirmed by the similarity of Sorensen and Jaccard indices.

The synthesis and the exploitation of data relating to floristic settings and edaphic measures, carried out by the FCA and the AHC, highlight the impact of the anthropic action on the distribution of vegetation formations of white wormwood. The Asteraceae and Poaceae are the families that are most represented in the study area. The biological characterization shows the dominance of therophytes. For the phytogeographical characterization, it is the Mediterranean component which dominates all of the stations studied.

In the light of these results, we can focus on the interest and the constructive impact of the exclosure on the recovery rate of the vegetation, the floristic richness and the phytomass. The exclosure account among the efficient means and less costs for the rehabilitation of rangelands disrupted. Actions for conservation must be carried out to save this heritage which incurs major risks of genetic and biological collapse. These actions for the conservation of biological diversity should first and foremost focus on the safeguarding of ecosystems because the protection of species is illusory if we do not protect simultaneously their natural habitats [36].

Finally, the evaluation of plant diversity of white wormwood steppe ecosystem of the explored area as presented in this present work is preliminary and far from being exhaustive. In fact, we are projecting to extend it in space and time for a better characterization in order to identify more factors that govern the operation, evolution and dynamics of this ecosystem subjected to various offenses.

\section{Acknowledgements}

We thank the High Commission at the development of the steppe and the national office of meteorology of Saida to have provided us the necessary data to carry out this work.

\section{References}

[1] Benabadji, N. and Bouazza, M. (2000) Contribution à une étude bioclimatique de la steppe à Artemisia herba-alba Asso. dans l’Oranie (Algérie occidentale). Sécheresse, 11, 117-123.

[2] Bouchetata, T.B. and Bouchetata, A.A. (2005) Dégradation des écosystèmes steppiques et stratégie de développement durable. Mise au point méthodologique appliquée à la Wilaya de Nâama (Algérie). Développement durable et territoires. Varia, 1-17. http://developpementdurable.revues.org/1339

[3] El Zerey, W., Bachir Bouiadjra, S.E. and Benslimane, M. (2009) L’écosystème steppique face à la désertification: Cas de la région d'El Bayadh, Algérie. Vertigo, 9. https://vertigo.revues.org/8821

[4] Ayad, N. (2008) Etude écophytochimique et apport nutritionnel de l'armoise blanche (Artemisia herba-alba Asso.) du sud Oranais dans l'alimentation du cheptel. Thèse de Doctorat d'état, Université de Sidi-Bel-Abbès, Algérie.

[5] Ayache, A. (2013) Dynamique des peuplements d'armoise blanche (Artemisia herba-alba Asso.) de la région d’El Aricha (Algérie occidentale). Thèse de Doctorat, Université de Sidi-Bel-Abbès, Algérie.

[6] Aidoud-Lounis, F. (1997) Le complexe alfa-armoise-sparte (Stipa tenacissima L., Artemisia herba-alba Asso., Lygeum spartum L.) des steppes arides d'Algérie: Structure et dynamique des communautés végétales. Thèse de Doctorat, Université d'Aix-Marseille.

[7] Ayad, N., Hellal, B. and Maatoug, M. (2007) Dynamique des peuplements d'Artemisia herba-alba Asso dans la steppe du Sud oranais (Algérie occidentale). Sécheresse, 18, 193-198.

[8] Hellal, B., Ayad, N., Ayache, A., Cherif, K. and Hellal, T. (2014) Biomasse et taux de recouvrement de l'armoise blanche des parcours steppiques du sud de la préfecture de Tlemcen. Revue Ecologie-Environnement, 10, 2014.

[9] Office national de la météorologie (ONM) (2011) Données climatiques 1978-2010.

[10] Braun-Blanquet, J. (1951) Pflanzensoziologie. 2tenAufl, Springer, Vienne.

[11] Djebaili, S. (1984) Recherches phytosociologiques et phytoécologiques sur la végétation des hautes plaines steppiques et de l'Atlas saharien algérien. OPU, Alger, 177 p. 
[12] Quézel, P. and Santa, S. (1962-1963) Nouvelle flore de l’Algérie et des régions désertiques méridionales. CNRS, Paris.

[13] Daget, P. and Godron, M. (1995) Pastoralisme: Troupeaux, espaces et sociétés. Hatier, Aupelf, Uref, Universités francophones.

[14] Devineau, J. (2001) Les espèces ligneuses indicatrices des sols dans les savanes et jachères de l'ouest du Burkina Fasso. Phytocoenologia, 3, 25-51.

[15] Aubert, G. (1978) Méthodes d'analyses du sol. C.R.D.P., Marseille.

[16] Gounot, M. (1969) Méthodes d'étude quantitatives de la végétation. Masson, Paris.

[17] Frontier, S. (1983) L’échantillonnage de la diversité spécifique. In stratégie d'échantillonnage en écologie. Frontier et Masson, Paris.

[18] Benzecri, J.P., Benzecri, F., Birou, A. and Blumenthal, S. (1973) L’analyse des données, Volume 2: L’analyse des correspondances. Dunod, Paris.

[19] Pouget, M. (1980) Les relations sol-végétation dans les steppes sud-algéroises. ORSTOM, Paris.

[20] Benzecri, J.P. (1984) Pratique de l'analyse des données. Analyse des correspondances et classification. Dunod, Paris.

[21] Aidoud, A. (1989) Les écosystèmes à Armoise blanche (Artemisia herba-alba Asso.). II: Phytomasse et productivité primaire. Biocénoses, 1, 70-90.

[22] Daget, P. and Poissonet, J. (1991) Prairies et pâturages: Méthodes d'étude. Institut de botanique, Montpellier.

[23] Daget, P. (1980) Sur les types biologiques en tant que stratégie adaptative (cas des thérophytes). In: Barbault, R., Blandin, P. and Meyer, J.A., Eds., Recherches d'écologie théorique, les stratégies adaptatives, Maloine, Paris, 89-114.

[24] Ozena, P. (1977) Flore du Sahara. CNRS, Paris.

[25] Barbero, M., Quézel, P. and Loisel, R. (1988) Perturbations et incendies en région méditerranéenne. Instituto Estudios Pyrenaicos Jaca, 12, 409-419.

[26] Henni, M. and Mehdadi, Z. (2012) Évaluation préliminaire des caractéristiques édaphiques et floristiques des steppes à armoise blanche dégradées réhabilitées par la plantation d’Atriplex dans la région de Saïda (Algérie occidentale). Acta Botanica Gallica, 159, 43-52. http://dx.doi.org/10.1080/12538078.2012.671640

[27] Danin, A. and Orshan, G. (1990) The Distribution of Rankiaer Life Forms in Israel in Relation to the Environment. Journal of Vegetation Science, 1, 41-48. http://dx.doi.org/10.2307/3236051

[28] Floret, C., Galan, M.J., Le Floc'h, E., Orshan, G. and Romane, F. (1990) Growth Forms and Phenomorphology Traits along an Environmental Gradient: Tools for Studying Vegetation? Journal of Vegetation Science, 1, 71-80. http://dx.doi.org/10.2307/3236055

[29] Barbero, M., Quézel, P. and Loisel, R. (1990) Les apports de la phytoécologie dans l’interprétation des changements et perturbations induits par l'homme sur les écosystèmes forestiers méditerranéens. Forêt méditerranéenne, 12, 194-215.

[30] Kadi-Hanifi, H. (2003) Diversité biologique et phytogéographique des formations à Stipa tenacissima L. de l’Algérie. Sécheresse, 3, 169-179.

[31] Nedjraoui, D. and Bédrani, S. (2008) La désertification dans les steppes algériennes: Causes, impacts et actions de lutte. http://vertigo.revues.org/5375

[32] Quézel, P. (1983) Flore et végétation de l'Afrique du Nord, leur signification en fonction de l'origine, de l'évolution et des migrations des flores et structures des végétations passées. Bothalia, 14, 411-416. http://dx.doi.org/10.4102/abc.v14i3/4.1186

[33] Le Houerou, H.N. (1995) Bioclimatologie et biogéographie des steppes arides de l’Afrique, diversité biologique, développement durable et désertification. Options méditerranéennes, série B: recherche et études, 1-396.

[34] Latreche, A. (2004) Ecologie fonctionnelle des écosystèmes steppiques du sud de la wilaya de Sidi-Bel-Abbès. Thèse, Université de Sidi-Bel-Abbès, Algérie.

[35] Benabadji, N., Bouazza, M., Metge, M. and Loisel, R. (1996) Description et aspects des sols en région semi-aride et aride au Sud de Sebdou (Oranie, Algérie). Bulletin Institut Sciences (Rabat), 20, 77-86.

[36] Lévêque, C. and Mounoulou, J.C. (2001) Biodiversité, Dynamique biologique et conservation. Dunod, Paris. 